\title{
APLIKASI METODE PERSIDANGAN SEMU PADA PEMBELAJARAN HUKUM PERS BAGI PENEGAK HUKUM
}

\author{
Muhammad Rustamaji \\ Dewi Gunawati \\ Fakultas Hukum dan FKIP UNS \\ e-mail: hatchi aiie@yahoo.com
}

\begin{abstract}
The study aims to obtain a method for learning pseudo trial press law for law enforcers. The design of this study is action research (participatory research actions) that combines legal research and studies in the education sector. Normative research methods and sociological studies used appropriate phasing in each year. The types of data used in this study include primary and secondary data. Data collection methods are interviews, questionnaires, and literature. Data processing is carried out through the stages of editing, coding, tabulating. Analysis technique using inductive and deductive thinking .. Observation of actual handling of the case became the foundation for further analysis based on legislation and groove trial. Observations thus further utilized to formulate the appropriate method of fictitious court press law. In the first year of this study produced findings: a) identification of two dominant factors typically by law enforcement officials in the press dispute, namely the use of Criminal Code offenses and negation case particularities press, b). finding of distinctiveness criteria law enforcement press located on the right of reply and the role of the Press Council in the settlement release applied to the fictitious trial methods, c) learned of discrepancies in the prototype method fictitious court press law enforcement against actual practice in the field of press due to the design of learning in one direction and instructional issues that are not collaborative. Furthermore, the results of this study indicate that a) the dominant factor affecting the typical law enforcement officials in the press dispute actually consists of the application of the dominant offense in the Criminal Code as an affront legal snares for members of the press, and did not understand the uniqueness of dispute settlement in the groove press releases as Act mandated by the press, $b$ ) uniqueness lies in the settlement conference where the submission of the right of reply, complaints to the Press Council, until the publication of the Press Council rekomendasai that preceded the litigatif c) discrepancies prototype artificial methods of learning trials with the reality of law enforcement is due to the instructional design of the course and instructional problems that actually can be parsed by the collaborative.
\end{abstract}

Keywords: method, fictitious trial, the press law.

\begin{abstract}
Abstrak
Penelitian bertujuan untuk memeroleh suatu metode persidangan semu dalam pembelajaran hukum pers bagi penegak hukum. Desain penelitian ini merupakan penelitian aksi (partisipatori actions research) yang memadukan penelitian hukum dan penelitian di sektor pendidikan. Metode penelitian yuridis normatif maupun sosiologis digunakan sesuai pentahapan penelitian di setiap tahunnya Jenis data yang digunakan dalam penelitian ini meliputi data primer dan sekunder. Metode pengumpulan data yang ialah wawancara, angket, dan studi pustaka. Pengolahan data dilaksanakan melalui tahap editing, coding, tabulating. Teknik analisis menggunakan metode berpikir induktif dan deduktif. Pengamatan penanganan kasus senyatanya menjadi pijakan untuk selanjutnya dianalisis berdasarkan perundangan dan alur persidangan. Hasil pengamatan demikian selanjutnya dimanfaatkan untuk memformulasikan metode persidangan semu yang sesuai ketentuan hukum pers. Pada tahun pertama penelitian ini menghasilkan temuan: a) teridentifikasinya dua faktor dominan tipikal penegakan hukum oleh aparat dalam sengketa pers, yaitu penggunaan delik KUHP dan penegasian kekhasan perkara pers; b) ditemukannya kriteria kekhasan penegakkan hukum pers yang terletak pada hak jawab dan peran Dewan Pers dalam penyelesaian perkara pers yang diaplikasikan pada metode persidangan semu; c) diketahuinya ketidaksinkronan prototipe metode persidangan semu hukum pers terhadap praktik senyatanya penegakan hukum di bidang pers akibat desain pembelajaran satu arah dan permasalahan instruksional yang tidak kolaboratif. Selanjutnya, hasil penelitian ini menunjukkan bahwa a) faktor dominan yang memengaruhi tipikal penegakan hukum oleh aparat dalam sengketa pers sejatinya terdiri atas dominannya penerapan delik penghinaan dalam KUHP sebagai jerat hukum bagi insan pers, dan tidak dipahaminya kekhasan penyelesaian sengketa pers dalam alur penyelesaian perkara pers sebagaimana diamanatkan oleh Undang-Undang pers; b) kekhasan penyelesaian perkara pers terletak pada keberadaan pengajuan hak jawab, pengaduan kepada Dewan Pers, hingga terbitnya rekomendasai
\end{abstract}


dari Dewan Pers yang mendahului proses litigatif; c) ketidaksinkronan prototipe metode pembelajaran persidangan semu dengan kenyataan penegakkan hukum lebih disebabkan pada desain pembelajaran satu arah dan permasalahan instruksional yang sejatinya dapat diurai dengan jalan kolaboratif.

Kata kunci: metode, persidangan semu, hukum pers.

\section{A. Pendahuluan}

Kekerasan yang menempatkan wartawan sebagai korban dalam menjalankan profesi jurnalistiknya (Angkasa, Agus Raharjo, 2007:119), masih saja terulang. Tewasnya wartawan Radar Bali AA Narendra Prabangsa yang diduga karena pemberitaannya, dan Marion Branden Mra wartawan TV Mandiri Papua yang ditikam di atas kapal seusai meliput (Hendaryana, 2010:1), maupun serentetan gugatan dan tuntutan hukum berdasarkan KUHP terhadap media dengan permintaan ganti kerugian mencapai miliaran rupiah, dengan dalih pencemaran nama baik, kabar bohong, dan fitnah, terhadap materi yang diberitakan, benar-benar bukan isapan jempol belaka.

Mencermati fenomena demikian, perguruan tinggi, khususnya fakultas hukum sejatinya berpotensi besar dalam melahirkan penegak hukum generasi baru yang teknologis-humanis (Satjipto Raharjo,tt:5) serta memiliki integritas dan idealisme hukum, yaitu generasi penegak hukum yang memiliki idealisme untuk menjaga kebebasan dan kemerdekaan pers. Oleh karenanya, pendidikan bagi penegak hukum; polisi, jaksa, hakim dan advokat menjadi penting dilakukan. Penegak hukum yang mengerti betul peran dan profesinya, tentu tidak akan menggunakan delik yang diatur dalam Kitab Undang-Undang Hukum Pidana (KUHP) (R. Soesilo, 1996:2) dalam menghadapi perkara pers, melainkan menggunakan mekanisme penyelesaian perkara pers sebagaimana diatur dalam UndangUndang Nomor 40 Tahun 1999 tentang Pers, sayangnya hal sebaliknya yang justru terjadi. Oleh karena itu, adanya metode pengenalan kasus pers sejak dini menjadi penting keberadaannya.

Pengenalan terhadap hukum pers melalui teoriteori, doktrin dan dasar hukum yang selama ini diajarkan tanpa kedekatan secara empirik. Permasalahan ini ialah bagaimana metode persidangan semu dalam aktivitas pembelajaran hukum pers bagi penegak hukum maupun calon penegak hukum (mahasiswa fakultas hukum)?

\section{B. Metode Penelitian}

Desain penelitian ini merupakan penelitian aksi (partisipatori actions research) (M. Atwi Suparman. 2005:38) yang memadukan penelitian hukum dan penelitian di sektor pendidikan. Untuk itu metode penelitian yuridis normatif maupun yuridis sosiologis digunakan sesuai pentahapan penelitian di setiap tahunnya. Pelaksanaan penelitian pada tahun pertama, studi induktif-deduktif dilakukan terhadap faktor-faktor dominan yang memengaruhi suatu tipikal penegakan hukum oleh aparat penegak hukum dalam menangani sengketa pers. Studi induktif-deduktif ini juga dimaksudkan untuk menemukan kriteria-kriteria tertentu dalam analisis perancangan aplikasi metode persidangan semu dalam pembelajaran hukum pers bagi mahasiswa sebagai calon penegak hukum, maupun bagi penegak hukum. Arahan untuk mengadakan pengkajian sinkronisasi prototipe metode persidangan semu dalam pembelajaran hukum pers juga dilakukan dengan kerjasama Lembaga Bantuan Hukum (LBH) Pers Jakarta dan Dewan Pers, atas praktik beracara aparat penegak hukum, khususnya dalam penegakkan hukum pers. Pendekatan aksi ini disesuaikan dengan objek penelitian yang berupa proses pembelajaran yang berlangsung dalam waktu yang cukup panjang dan lama, kondisi demikian membutuhkan keterlibatan peneliti dalam kegiatan tersebut. Guna memperoleh kecukupan pemenuhan data dalam penyusunan model pembelajaran persidangan semu pers sebagaimana dirumuskan dalam tujuan dan urgensi penelitian, diperlukan lokasi utama dan lokasi pendukung yang representatif dalam melaksanakan penelitian. Lokasi utama diarahkan mulai dari Dewan Pers, Lembaga Bantuan Hukum Pers Jakarta, Laboratorium IImu Hukum di Fakultas Hukum yang tergabung dalam Region Jawa Tengan dan DIY, serta Komunitas Peradilan Semu setempat. Adapun jenis data yang peneliti gunakan dalam penelitian ini berasal dari data primer dan data sekunder. Metode pengumpulan data yang digunakan dalam penelitian action research, yaitu; wawancara, angket, dan studi pustaka (Mohammad Nazir. 1985:234). Pada penelitian kuantitatif, pengolahan data secara umum dilaksanakan melalui tahap memeriksa (editing), proses pemberian identitas (coding) dan proses membeberkan (tabulating) (Burhan Bungin. 2005:25). Analisis data dilakukan secara induktif dan deduktif.

\section{Hasil Penelitian dan Pembahasan}

1. Pembelajaran dengan Model Persidangan Semu

Berdasarkan pilar-pilar teori pendidikan klasik, para pemikir Quantum Teaching telah 
menciptakan payung yang mensintesiskan semua teori menjadi sebuah 'alat' yang mudah digunakan. Cara-cara praktis untuk memengaruhi keadaan mental pelajar diuraikan dengan jelas. Quantum teaching selalu berpusat pada 'apa yang masuk akal bagi para pelajar'(Michael Grinder dalam Bobbi de Porter dkk (Pujian Untuk Quantum Teaching), 2007:xi). Langkah dan pentahapan dalam buku yang mengorkestrasikan kesuksesan siswa dalam dua sesi utama konteks dan konten inilah yang menjadi patokan (state of the art) peneliti dalam penelitian penciptaan metode persidangan semu dalam pembelajaran hukum pers dimaksud.

Kerangka konseptual penciptaan suatu metode persidangan semu dalam pembelajaran hukum pers bagi penegak hukum yang mengintegrasikan antara teori dan praktek, pada prinsipnya berusaha menghadirkan konteks maupun konten persidangan ke dalam kelas untuk diamati dan dipelajari oleh peserta didik (M.Rustamaji. Dewi Gunawati, 2011:59), baik dari kalangan mahasiswa (calon penegak hukum), maupun penegak hukum. Metode pembelajaran demikian menggunakan pendekatan perkembangan yang menempatkan peserta didik sebagai pembelajar sejati dalam konteks historis pendidikan progresif. Peserta didik dalam hal ini diposisikan menjadi titik awal pengembangan metode. Inilah yang disebut kelas progresif yang berpusat pada peserta didik (student oriented).

Pelajaran bagi pendidikan progresif adalah bahwa pendidikan itu secara agak mendesak menuntut adanya suatu filsafat pendidikan yang didasarkan pada pengalaman. Dengan demikian, ide bahwa suatu teori yang koheren mengenai pengalaman memberikan arah positif pada seleksi dan organisasi terhadap berbagai materi dan metode pendidikan yang cocok, menuntut adanya upaya untuk memberikan arah baru bagi tugas lembaga pendidikan. Dari sudut pandang ini, prinsip kontinuitas pengalaman berarti bahwa setiap pengalaman mengambil sesuatu dari semua pengalaman yang berlangsung sebelumnya dan dengan cara tertentu mengubah kualitas semua pengalaman yang menyusul. Sehingga demikian setiap pengalaman sejati akan memberi kesan dan memiliki suatu sisi aktif yang dalam tigkat tertentu mengubah semua kondisi objektif dimana pengalaman itu diperoleh. Dalam konteks pendidik, dapat dicermati pandangan John Dewey sebagai berikut.
"Suatu tanggungjawab utama dari para pendidik ialah bahwa mereka tidak hanya menyadari prinsip umum mengenai terbentuknya pengalaman aktual oleh berbagai kondisi lingkungan, tetapi mereka juga secara konkret menyadari keadaan sekitar macam manakah yang kondusif untuk memperoleh berbagai pengalaman yang menyebabkan proses pertumbuhan (John Dewey. 2008:29)"

Mencermati konsepsi pengalaman dalam pendidikan progresif, maka setidaknya terdapat tiga macam cakupan dalam pelaksanaan program inovasi metode pembelajaran kelas yang berpusat pada peserta didik ini, yaitu sebagai berikut.

a. Konstruktifisme. Para ahli konstruktif meyakini bahwa pembelajaraan terjadi ketika peserta didik berusaha memahami dunia disekeliling mereka. Jacqueline dan Martin Brooks mengemukakan, pembelajaran menjadi proses interaktif yang melibatkan teman sebaya, orang lain, dan lingkungan. Mereka memahami apa yang terjadi di sekeliling mereka dengan mensintesa pengalaman baru dengan apa yang telah mereka pahami sebelumnya (Jacqueline dan Martin Brooks. 2000:8). Bedah kasus, simulasi reka ulang perkara, maupun permainan peran (role playing) dalam miniatur persidangan semu, merupakan contoh aplikasi riil yang dapat dikembangkan untuk dijadikan "jembatan" penghubung antara law in book dan law in action dalam inovasi model pembelajaran hukum pers bagi peserta didik.

b. Metode terkini yang sesuai perkembangan. Metode yang sesuai perkembangan adalah metode yang didasarkan pada pengetahuan mengenai perkembangan peserta didik. Program yang disesuaikan dengan perkembangan, dirancang untuk membantu peserta didik menjawab pertanyaan-pertanyaan mereka sendiri. Saat peserta didik mengajukan pertanyaan, timbullah minat, motivasi dan perhatian mereka dengan sendirinya. Peran dosen di sini adalah menunjukkan jalan untuk menemukan jawaban yang memuaskan peserta didik, tanpa terlalu menyederhanakan informasi, atau menghujani peserta didik dengan informasi yang tidak dapat dipahami (Jacqueline dan Martin Brooks. 2000:9)

c. Pendidikan progresif. John Dewey yang dikenal sebagai bapak pendidikan progresif, menekankan bahwa pendidikan 
dipandang sebagai proses sepanjang hidup (kategori kontinuitas atau rangkaian kesatuan pengalaman), bukanlah persiapan untuk masa mendatang (John Dewey, 2008:21). Dewey berpendapat bahwa pendidikan yang ditujukan untuk persiapan pada masa dewasa, telah menyangkal adanya kegembiraan dan rasa ingin tahu yang terdapat dalam diri peserta didik, yang mereka bawa ke sekolah/kampus. Pendidikan demikian juga mengalihkan fokus pembelajaran yang seharusnya ditujukan terhadap minat dan kemampuan yang saat ini nyata-nyata dimiliki peserta didik, dialihkan menjadi fokus terhadap anggapan-anggapan abstrak tentang hal-hal yang mungkin mereka ingin capai di masa mendatang (John Dewey, 2008:10). Dalam hal ini, inovasi pembelajaran dengan model persidangan semu diharapkan memacu peserta didik untuk menggali potensi mereka dalam menguasai materi yang disukai dan diterapkan untuk mencari solusi terhadap simulasi permasalahan hukum maupun kasuistik yang dihadapi. Sehingga peserta didik terhindar dari ambisi memburu nilai tinggi tanpa orientasi keilmuan yang memadai.

Adapun mengenai konten atau substansi metode persidangan semu dalam pembelajaran hukum pers bagi penegak hukum berkaitan dengan ajaran relativisme Gustav Radbruch khususnya mengenai antinomi-antinomi ide hukum (antinomies of the idea of law) (Kurt Wilk dalam Hari Purwadi. 2007:10). Gustav Radbruch mengemukakan bahwa beranjak dari konsep hukum sebagai konsep budaya (cultural concept), yaitu konsep yang berhubungan dengan nilai, maka ia menekankan pada nilai hukum (the value of law) dan ide hukum (the idea of law). Hukum menurut maknanya dimaksudkan untuk memenuhi ide tersebut. Ide hukum yang dimaksud, ditemukannya dalam tiga elemen, yaitu keadilan (justice), kegunaan atau kemanfaatan (expediency) dan kepastian hukum (legal certainty). Sedangkan mengenai korelasi antara hukum dan hakim yang tampak dalam praktek hukum dimaksudkan untuk mengetahui cara hukum digunakan dan dimaknai di depan pengadilan. Setidaknya terdapat empat konsep yang bersumber dari ajaran yang berbeda seperti dikemukakan oleh Theo Huijbers, yaitu legisme (ideenjurisprudenz), ajaran hukum bebas (frei rechtsiehre), interessenjurisprudenz, dan idealisme hukum baru (new legal idealism) (Otje Salman dan Anton F. Susanto. 2004:20).

Berdasarkan kajian pustaka yang dilakukan, diketahui bahwa pandangan yang legistis memandang praktek di pengadilan tidak lain sebagai penerapan peraturan perundangan dalam perkara-perkara konkret secara rasional belaka. Hukum dipandang sebagai suatu sistem logis yang berlaku bagi semua perkara karena bersifat rasional. Teori rasionalitas sistem hukum pada abad ke-19 ditunjuk dengan istilah ideenjurisprudenz. Sedangkan ajaran hukum bebas yang dikemukakan oleh mazhab realisme Hukum Amerika membela kebebasan yang besar bagi sang hakim. Seorang hakim dapat menentukan putusannya dengan tidak terikat pada peraturan perundangundangan. Dengan demikian ajaran ini merupakan suatu antitesis terhadap ideenjurisprudenz. Sementara itu, interessenjurisprudenz tetap mempertahankan normanorma hukum sebagai penentu dalam proses di pengadilan, walaupun situasi konkret diperhitungkan juga sepenuhnya. Teori ini dikualifikasi sebagai penemuan hukum (rechtsvinding), artinya hakim mencari dan menemukan keadilan dalam batas normanorma yang telah ditentukan dengan menerapkannya secara kreatif pada tiap-tiap perkara konkret. Sedangkan di pihak lain, dalam idealisme hukum baru, undang-undang memiliki bobot normatif bagi penerapan hukum, sebab Undang-Undang mencerminkan cita-cita hidup yang dituju dalam membentuk suatu tata hukum. Idealisme baru ini hanya dapat timbul dalam rangka sistem hukum kontinental. Tekanan yang terjadi dalam idealisme hukum baru, di samping Undang-Undang juga terletak pada cita-cita bangsa, walaupun belum dihayati sepenuhnya. Jika mengikuti argumentasi Theo Huijbers, dalam konteks Hukum Nasional, hakim di Indonesia secara konsepsional lebih cenderung pada idealisme hukum baru (new legal idealism) tersebut.

\section{Identifikasi Faktor-faktor Dominan Tipikal Penegakan Hukum oleh Aparat dalam Sengketa Pers}

Faktor dominan yang memengaruhi tipikal penegakan hukum oleh aparat (penyidik, penuntut umum, dan hakim) dalam sengketa pers sejatinya terdiri atas dua faktor dominan. Di satu sisi faktor dominan penerapan delik penghinaan dalam KUHP sebagai jerat hukum bagi insan pers, menjadi faktor utama yang berhasil diungkap. Adapun faktor kedua yaitu 
tidak dipahaminya kekhasan penyelesaian sengketa pers dalam alur penyelesaian perkara pers sebagaimana diamanatkan oleh Undang Undang Pers. Kedua faktor dominan demikian pada fase selanjutnya menjadi efek domino terhadap implementasi penegakan hukum pers yang dapat dicermati dalam beberapa kasus yang berhasil dikumpulkan.

a. Faktor Dominan Penerapan Delik Penghinaan dalam KUHP Sebagai Jerat Hukum Bagi Insan Pers

Berdasarkan pembedahan atas beberapa kasus berikut, dapat diungkapkan bahwa kecenderungan penggunaan pasal pencemaran nama baik, berita bohong dan fitnah masih banyak ditemukan dalam penegakan hukum di bidang pers. Mencermati serentetan gugatan hukum terhadap media dengan tuntutan miliaran rupiah dengan dalih pencemaran nama baik, kabar bohong dan fitnah terhadap materi yang diberitakan, dialami oleh beberapa media yang berani memberitakan (membongkar) kasus yang merugikan hajat hidup orang banyak. Contoh kasus, PT. Asian Agri Group (AAG) yang menggugat Majalah Tempo atas berita investigasi tentang dugaan penggelapan pajak oleh PT AAG, kemudian kasus PT. Riau Andalan Pulp And Paper (RAPP) yang menggugat Koran Tempo atas berita dugaan pembalakan liar oleh RAPP, adalah sedikit gambaran kasus perdata yang dimejahijaukan. Tidak hanya melalui jalur perdata, dakwaan dengan ancaman pidana penjara juga menjadi balasan bagi beberapa jurnalis atas hasil kerjanya dalam memberitakan atau membongkar suatu skandal. Hal tersebut pernah dialami oleh Risang Bima Wijaya, wartawan Radar Jogja, karena beritanya yang mengangkat skandal pelecehan seksual oleh seorang bos koran terhadap karyawatinya. Risang harus mendekam di Lembaga Pemasyarakatan Cebongan karena karya jurnalistiknya itu.

Gambaran contoh kasus di atas menunjukan faktor dominan pertama, yaitu penggunaan pasal-pasal berkait delik penghinaan dalam menghadapi kebebasan menyampaikan pikiran dan pendapat melalui pers. Faktor dominan penggunaan KUHP demikian pada tahap selanjutnya tidak lagi membedakan perbuatan yang dilakukan merupakan tindakan individual yang menyerang kehormatan seseorang, atau justru pengungkapan kebenaran bagi khalayak ramai oleh pers. Pada akhirnya sinkronisasi antara delik penghinaan dan konsistensi perlindungan kebebasan berpendapat tidak lagi menjadi pembanding dalam penegakan hukum di bidang pers. Padahal apabila ditelaah lebih rinci guna menemukan koridor jaminan kemerdekaan pers serta kebebasan mengemukakan pikiran dan pendapat yang disandingkan dengan penegakkan hukum pers, akan ditemukan dua tahap sinkronisasi yaitu secara vertikal antara perundangan hukum positif (KUHP, UU Pers, UU ITE) terhadap konstitusi, dan sinkronisasi horisontal antar produk hukum positif tersebut.

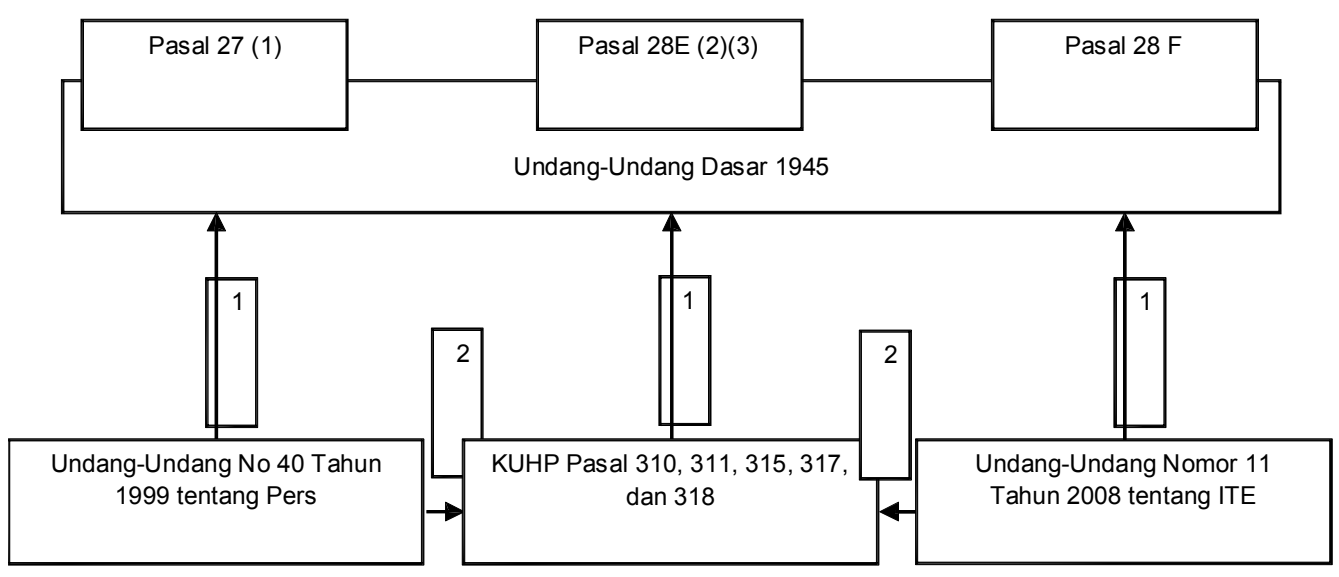

Gambar 1. Skematik Sinkronisasi Vertikal Horizontal 
Berkenaan dengan skematik sinkronisai vertikal dan horizontal yang dilakukan terhadap UUD 1945, KUHP, UU Pers, dan UU ITE di atas, dapat dilihat beragam sikronisasi sebagai berikut.

1) Berdasarkan penguraian sinkronisai vertikal antara KUHP terhadap UUD 1945, dapat dilihat ketidaksinkronan pengaturan delik penghinaan, maupun pencemaran nama baik, yang diarahkan kepada pers yang menjalankan fungsi jurnalistiknya

2) Mencermati pola hubungan yang ternyata menunjukkan keberlanjutan pengaturan antara Undang-Undang Pers terhadap UUD 1945, maka tidak sulit untuk menyatakan bahwa terdapat pola sinkronisasi yang selaras diantara kedua produk hukum dimaksud. Artinya dalam komposisi pengaturan vertikal, kedua produk hukum ini tidak terdapat posisi diametral yang saling menegasikan dalam menjamin kemerdekaan pers beserta kebebasan mengemukakan pikiran dan pendapat bagi warga negara sebagai sebuah hak asasi dan amanat konstitusi.

3) Menarik konklusi UUD 1945 terhadap UU ITE, terdapat dua poin pengaturan ITE terhadap jaminan kemerdekaan pers serta kebebasan mengemukakan pikiran dan pendapat dapat diketahui sinkronisasi paruh yang menunjukkan fenomena 'pedang bermata dua'. Dikatakan fenomena 'pedang bermata dua' kembali terjadi dalam pengaturan Pasal 27 jo Pasal 45 UU ITE karena, di satu sisi ketentuan Pasal 27 jo Pasal 45 dalam batang tubuh UU ITE tersebut memberikan kebebasan pers mengeluarkan pikiran dan pendapat, namun disaat yang sama pers bisa saja tersandera dengan pemidanaan penjara dan/atau denda, yang siap mengancam atas tindak pidana yang dilakukan.

4) Menelaan sinkronisasi UU Pers terhadap KUHP, diketahui bahwa kedua norma dalam dua ketentuan hukum yang berbeda tersebut jika tidak menempuh jalan tengah dalam penegakannya, secara gamblang dapat segera diketahui adanya ketidaksinkronan yang kemudian terjadi.

5) Jika dikaji hubungannya, UU ITE dan KUHP ini mempunyai sinkronisasi yang baik dalam mengatur pembatasan kebebasan menyampaikan pendapat dan pikiran serta kemerdekaan pers.

6) Adapun mengenai sinkronisasi antara UU Pers dan UU ITE, terdapat dua kemungkinan taraf sinkronisai yaitu, jika UU ITE pada Pasal 27 jo Pasal 45 dimaksud tidak ditujukan pengatur aktivitas pers karena sudah mengindahkan kode etik pemberitaan, dan tidak menarget pers sebagai sasaran pengaturan pasal dimaksud, maka kemerdekaan pers maupun kebebasan menyampaikan pendapat dan pikiran tentu sangat terjamin. Pada tahap selanjutnya, pengecualian tujuan ini menunjukkan adanya sinkronisasi yang selaras di antara UU Pers dan UU ITE. Namun, jika sebaliknya, pers dimasukkan pula dalam cakupan subyek hukum, baik individual maupun entitas sosial, pendidikan maupun bisnis, tanpa ada pengecualian di hadapan hukum, maka yang terjadi adalah ketidaksinkronan antara kedua produk hukum dimaksud.

b. Kekhasan Penyelesaian Sengketa Pers dalam Alur Penyelesaian Perkara Pers

Penanganan tindak pidana yang dilakukan berkaitan dengan pers memiliki keunikan tersendiri jika dibandingkan dengan penanganan tindak pidana yang lain. Meskipun tidak terdapat hukum acara khusus untuk menegakan hukum dalam lingkup pidana pers, tetapi terdapat prosedur tertentu yang harus dilalui. Keunikan prosedur penanganan tindak pidana pers dimaksud, dapat dicermati dari institusi yang terlibat dalam penanganan penegakan hukum pers, regulasi dan perundangan yang digunakan, unsur pidana yang dapat dikategorikan untuk menentukan adanya kesalahan, pembuktian tindak pidana, serta alur penangananya. 


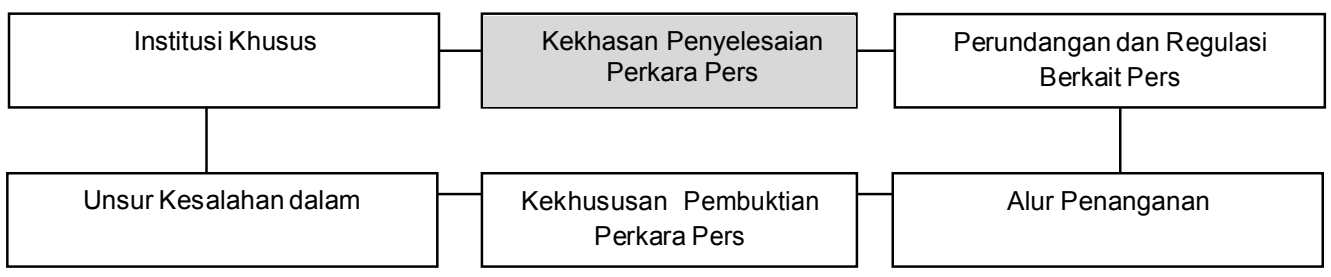

Gambar 2. Skematik Kekhasan Perkara Pers

Berpijak pada skematik di atas, dapat diketahui bahwa penanganan perkara pers melibatkan institusi khusus yang tidak ditemukan dalam penegakan hukum pada perkara lain, baik ordinary crime maupun extraordinary crime. Institusi khusus dimaksud adalah Dewan Pers. Menurut ketentuan Pasal 5 ayat (2) UndangUndang Nomor 40 Tahun 1999 tentang Pers, fungsi Dewan Pers antara lain menetapkan dan mengawasi pelaksanaan Kode Etik Jurnalistik dan memberikan pertimbangan dan mengupayakan penyelesaian pengaduan masyarakat atas kasus-kasus yang berhubungan pemberitaan pers. Namun jika kasus yang bersangkutan telah ditangani pihak kepolisian, Dewan Pers tidak akan menangani pengaduan tersebut.

Berdasarkan ketentuan dimaksud, dapat dipahami bahwa Dewan Pers merupakan lembaga regulator di bidang pers, penegak kode etik, dan lembaga yang menangani kasus pemberitaan pers. Menurut Pasal 1 Prosedur Pengaduan di Dewan Pers, pengadauan masyarakat yang ditangani Dewan Pers adalah masalah yang terkait dengan pelaksanaan Kode Etik Jurnalistik, dan kasuskasus lain yang menyangkut pemberitaan.

Apabila terdapat pengaduan, Dewan Pers akan mengupayakan musyawarah antara pengadu dan media yang diadukan. Namun jika tidak tercapai mufakat, maka Dewan Pers akan melakukan pemeriksaan lebih lanjut. Pemeriksaan dilakukan melalui sidang pleno yang akan menghasilkan Pernyataan penilaian dan Rekomendasi yang dikirim kepada para pihak, serta diumumkan secara terbuka. Pada tahap selanjutnya, perusahaan pers yang diadukan wajib mematuhi pernyataan penilaian dan rekomendasi. Jika penilaian dan rekomendasi demikian tidak dipatuhi, Dewan Pers akan membuat rekomendasi selanjutnya yang antara lain agar kasus tersebut ditangani kepolisian atau digugat secara perdata oleh pihak yang merasa dirugikan atas pemberitaan yang dilansir.

Melalui mekanisme pleno oleh Dewan Pers inilah terdapat alur pemeriksaan yang khas dan mendahului proses penegakan hukum seperti yang selama ini dikenal. Pada sisi perkara pers demikian, muncullah beberapa alat bukti baru yang belum dikenal dalam Pasal 184 KUHAP. Beberapa alat bukti tersebut, antara lain sebagai berikut.

1) Karya jurnalistik yang dipublikasikan. Dalam hal ini obyek perkara pidana pers harus berbasis pada berita, baik cetak, elektronik maupun media internet. Oleh karenanya berita merupakan bukti utama untuk dilakukannya sebuah pemeriksaan pembuktian. Mengacu pada ketentuan Undang-undang Nomor 11 Tahun 2008 tentang ITE, dapat diketahui bahwa pemberitaan baik cetak maupun melalui media internet dan hasil rekaman, dapat digunakan dan bernilai sebagai bukti.

2) Permohonan Wawancara. Alat bukti yang dapat menunjukkan apakah sang jurnalis telah mengupayakan dengan sungguh-sungguh langkah konfirmasi terhadap pihak yang merasa dirugikan, adalah permohonan wawancara. Wujud permohonan wawancara demikian dapat ditempuh dengan beragam cara yang lazim, antara lain melalui surat resmi, telepon, pesan singkat (sms), faksimail, email yang cara lain yang wajar.

3) Rekaman wawancara, alat bukti ini dimaksudkan untuk menunjukkan apakah pembuatan sebuah karya berita didasarkan pada sumber yang jelas dan terkonfirmasi.

4) Pernyataan Penilaian dan Rekomendasi Dewan Pers. Pernyataan dari 
Dewan Pers atas sebuah adauan pemberitaan merupakan alat bukti yang otentik karena diputuskan dalam sebuah sidang pleno terhadap dugaan adanya pelanggaran kode etik jurnalistik atas karya jurnalistik dimaksud.

5) Hak Jawab. Keberadaan hak jawab digunakan dalam pembuktian perkara pers berkait dengan apakah pers yang melakukan kekeliruan telah melayani hak jawab orang yang mendalilkan dirugikan. Tidak dilayaninya hak jawab demikian akan berakibat dilanggarnya kode etik jurnalistik dan bahkan pelanggaran hukum. Dengan demikian unsur kesalahan dalam perkara pers tidak semata berkaitan dengan pelanggaran hukum, namun bersangkutpaut pula dengan kepatuhan terhadap regulasi standar kerja jurnalistik dan tata perilaku penyiaran maupun ketentuan berkait kode et ik jurnalistik.

3. Kriteria Kekhasan Penegakan Hukum Pers dalam Perancangan Aplikasi Metode Persidangan Semu.

Secara berurutan, alur rangkaian penyelesaian perkara pers dimulai dari pengajuan hak jawab, pengaduan kepada Dewan Pers, hingga terbitnya rekomendasai dari Dewan Pers. Jika tahapan awal demikian memunculkan rekomendasi penanganan perkara oleh aparat penegak hukum, maka tindakan penyelidikan, penyidikan, penuntutan hingga pemeriksaan di muka persidangan, merupakan tindakan penegakkan hukum selanjutnya.

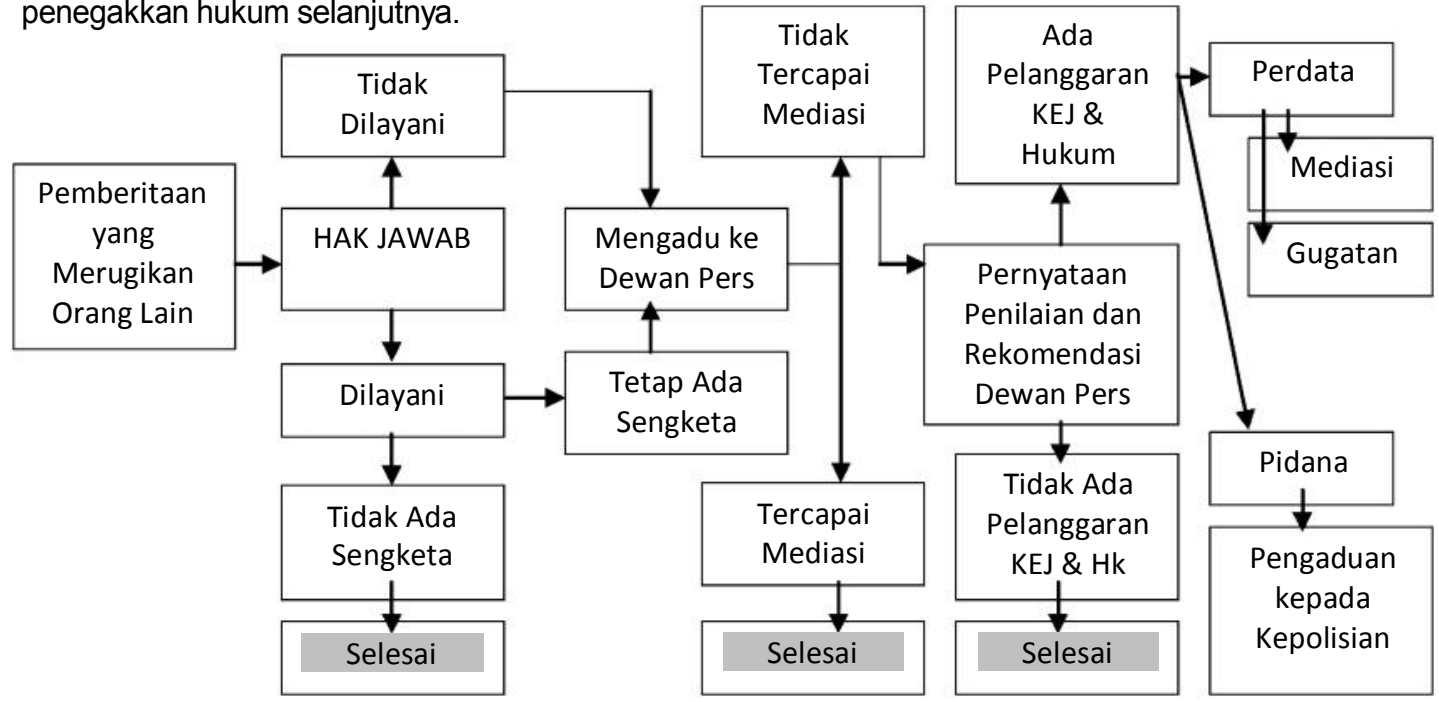

Gambar 3. Skematik Alur Penyelesaian Perkara Pers Melalui Dewan Pers
Keberadaan pengajuan hak jawab merupakan hal utama yang harus ditempuh oleh pihak yang merasa dirugikan oleh sebuah pemberitaan. Dalam hal ini pers wajib melayani hak jawab tersebut. Apabila pers tidak memenuhi hak jawab bagi pihak yang dirugikan, maka orang yang dirugikan tersebut dapat melakukan pengaduan kepada Dewan Pers. Atas pengaduan pihak yang tidak dilayani hak jawabnya, Dewan Pers akan memediasi antara pihak yang dirugikan atas pemberitaan yang dimuat, dengan pihak perusahaan pers. Apabila proses mediasi ini tidak memeroleh solusi atas permasalahan yang disengketakan, maka Dewan Pers akan menggelar sidang pleno guna mengeluarkan pernyataan penilaian dan rekomendasi atas karya jurnalistik yang diadukan. Langkah selanjutnya setelah diperoleh penyataan penilaian dan rekomendasi dari Dewan Pers, terdapat dua kemungkinan yang dapat tersaji. Jika penilaian dan rekomendasai menyatakan tidak diketemukan pelanggaran Kode Etik Jurnalistik dan kepatuhan tata kerja jurnalistik, maka perkara dinyatakan selesai. Namun jika sebaliknya penilaian dewan pers menyatakan terdapat pelanggaran Kode Etik Jurnalistik dalam karya jurnalistik yang diadukan, maka rekomendasi dalam jalur perdata maupun pidana dapat ditindaklanjuti kepada penegak hukum di ranah litigasi.

Guna memberikan gambaran yang lebih utuh mengenai keunikan penanganan perkara pers, berikut disajikan skematik alur penangan perkara pers sebelum proses penegakkan hukum litigatif dilakukan (Tim LBH Pers. 2009:10). 
4. Sinkronisasi Prototipe Metode Persidangan Semu Hukum Pers dan Praktik Senyatanya Penegak Hukum.

Inventarisasi permasalahan sinkronisasi instruksional dalam pelaksanaan pembelajaran persidangan semu hukum pers sejatinya dapat difokuskan pada model desain pembelajaran yang menyajikan rencana pembelajaran dan prosedur pembelajaran beserta implementasinya. Berdasarkan penelitian yang dilakukan, ditemukan kendala yang terletak pada desain pembelajaran satu arah (teacher oriented) tanpa mencoba untuk membuka kesempatan bagi peserta didik untuk meraih pengalaman seluas-luasnya dalam proses belajarnya. Desain pembelajaran demikian semakin terakumulasi ketika perkembangan hukum terbaru tidak diikuti dengan semangat belajar pasca selesainya pendidikan hukum di bangku perkuliahan. Pada akhirnya penegakan hukum dilakukan dengan menyamaratakan penanganannya sebagaimana diatur dalam ketentuan hukum acara pidana yang dituangkan dalam KUHAP, tanpa terkecuali dalam bidang hukum pers. 


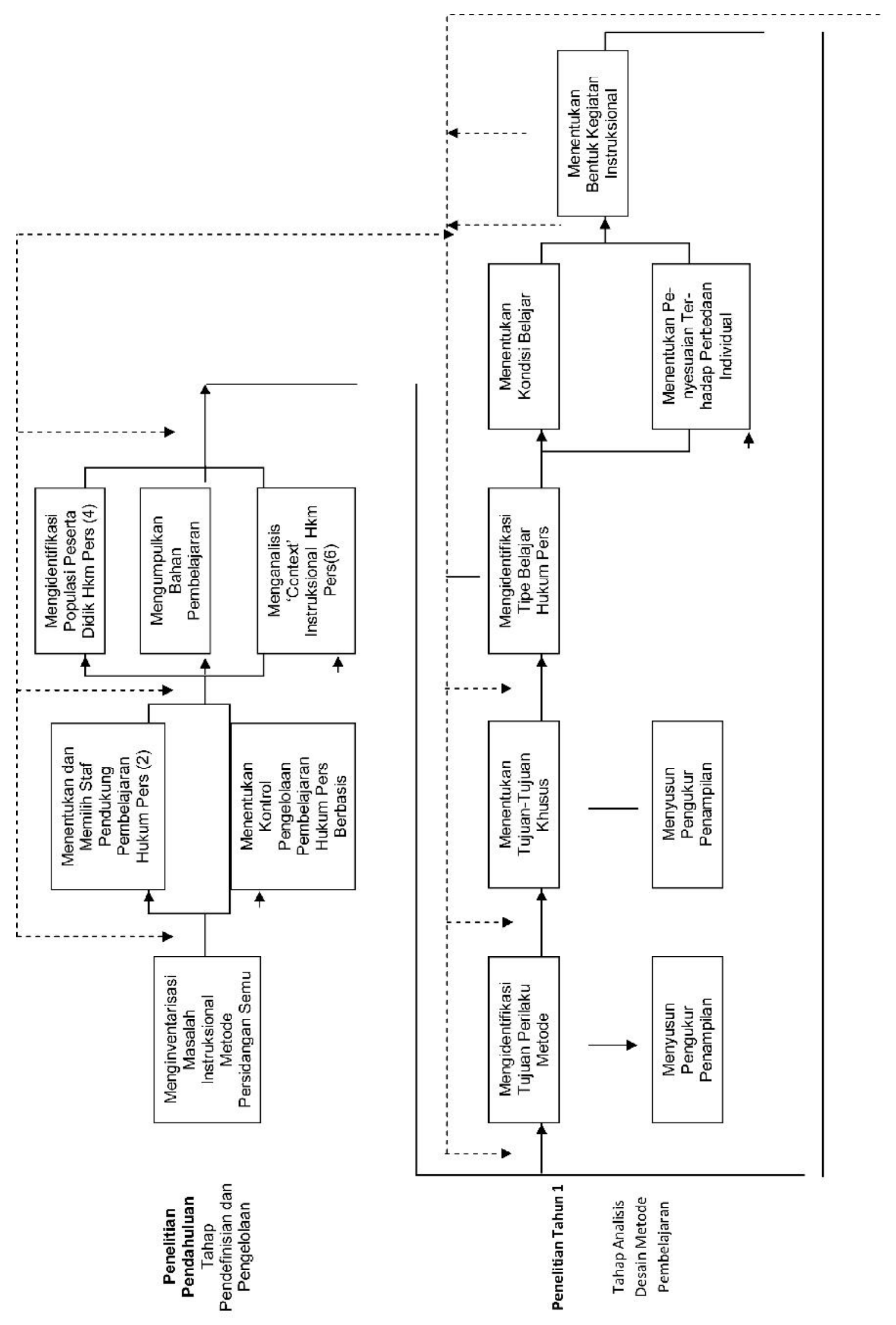

76 Yustisia Vol.1 No. 3 September -Desember 2012

Aplikasi Metode Persidangan Semu pada ... 


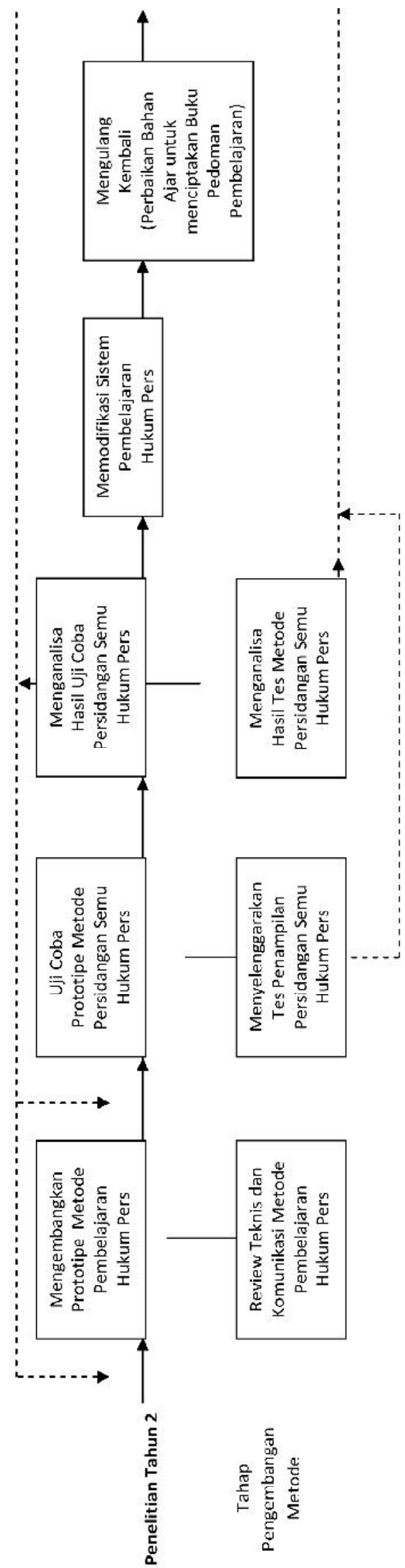

Yustisia Vol.1 No. 3 September-Desember 2012 
Atas fenomena praktis hukum demikian, langkah inventarisasi permasalahan instruksional dalam pelaksanaan pembelajaran persidangan semu pers, diarahkan untuk mencakup penentuan dan pemilihan staf pendukung pembelajaran. Pengkolaborasian antara praktisi hukum pers (LBH Pers, Dewan Pers), maupun akademisipun dilakukan. Langkah kolaboratifditempuh guna menanggulangi potensi hambatan gagalnya proses perbaikan pembelajaran hukum pers berbasis persidangan semu akibat terkendala pada staf pengajar yang merasa bisa mengajarkan apa saja tanpa mau memfokuskan diri dan memperbaharui informasi dalam bidang ilmunya. Penentuan kontrol pengelolaan bersifat normatif doktrinal sesuai ketentuan perundangan pers yang disinkronkan dengan tata cara dan acara dalam KUHAP. Namun hal demikian menjadi bermasalah ketika terjadi pembaharuanpembaharuan hukum acara seperti dalam penentuan alat bukti elektronik dan nilai pembuktian, misalnya. Pengidentifikasian populasi mahasiswa dapat tertolong dengan penciptaan kelas kecil, suasana rivalitas kompetitif dan fokus. Pengumpulan bahan pembelajaran diketahui sangat tertopang kecanggihan teknologi informasi melalui internet yang memudahkan up date data dan perkembangan hukum yang diperlukan dalam case study pembelajaran persidangan semu pers. Adapun analisis 'context' instruksional menempatkan peserta didik maupun aparat penegak hukum yang berada pada situasi persidangan yang sesungguhnya dengan memainkan role play persidangan semu dalam rangkaian pembelajaran interaktif, masih memerlukan pengkajian lanjutan.

\section{Simpulan}

Menelaah pertautan permasalahan dan pembahasan hasil penelitian, dapat disimpulkan sebagai berikut.

1. Faktor dominan yang memengaruhi tipikal penegakan hukum oleh aparat dalam sengketa pers sejatinya terdiri atas dominannya penerapan delik penghinaan dalam KUHP sebagai jerat hukum bagi insan pers, dan tidak dipahaminya kekhasan penyelesaian sengketa pers dalam alur penyelesaian perkara pers sebagaimana diamanatkan oleh undangundang pers.

2. Kekhasan penyelesaian perkara pers terletak pada keberadaan pengajuan hak jawab, pengaduan kepada Dewan Pers, hingga terbitnya rekomendasai dari Dewan Pers yang mendahului proses litigatif.

3. Ketidaksinkronan prototipe metode pembelajaran persidangan semu dengan kenyataan penegakkan hukum lebih disebabkan pada desain pembelajaran satu arah dan permasalahan instruksional yang sejatinya dapat diurai dengan jalan kolaboratif.

\section{Daftar Pustaka}

Angkasa, Agus Raharjo.2007. “Kedudukan Korban Tindak Pidana dalam Sistem Peradilan Pidana”. Jurnal Penelitian Hukum "Supremasi Hukum" Vol. 12 No. 2 Agustus 2007.

Bobbi de Porter dkk. 2007. Quantum Teaching Mempraktekkan Quantum Learning di Ruang-Ruang Kelas. Bandung: Kaifa

Burhan Bungin. 2005. Metodologi Penelitian Kuantitatif. Jakarta: Prenada Media.

Hari Purwadi. 2007. "Nilai Dasar dan Pendekatan Hukum dalam Pembentukan Putusan Pengadilan". Laporan Hasil Penelitian Kerjasama FHUNS-KY.

Hendrayana. 2010, Maret. "Kerangka Acuan Peradilan Semu Pers”. Jakarta: Yayasan LBH Pers

Jacqueline dan Martin Brooks. 2000. Menciptakan Kelas yang Berpusat pada Anak. Washington DC. (Versi Alih Bahasa-CRI Indonesia): Children's Resources International Inc.

John Dewey.1976. Philosophyof Education, The Middle Work of John Dewey. 1899-1924. Vol 7. Carbondale: Southem University Press. 2008. Pengalaman dan Pendidikan. Yogyakarta: Kepel Press

Mohammad Nazir. 1985. Metodologi Penelitian. Jakarta: Ghalia Indonesia 
M. Atwi Suparman. 2005. Desain Instruksional. "PEKERTI Mengajar di Perguruan Tinggi. Dirjen Dikti. PusatAntar Universitas untuk Peningkatan dan Pengembangan Aktivitas Instruksional". tp

M.Rustamaji, Dewi Gunawati.2011. Mootcourt 'Membedah Peradilan Pidana dalam Kelas Pendidikan Hukum Progresif. Surakarta: Mefi Caraka

Otje Salman dan Anton F. Susanto. 2004. Teori Hukum (Mengingat, Mengumpulkan, dan Membuka Kembali). Bandung: Refika Aditama

R. Soesilo. 1996. Kitab Undang Udang Hukum Pidana serta Komentar-komentarnya Lengkap Pasal Demi Pasal. Bogor: Politea

Satjipto Raharjo. 2005. "Delapan Puluh Tahun Pendidikan Tinggi Hukum Indonesia”. Makalah. Disampaikan pada Seminar Nasional dalam Rangka Dies Natalis Ke-48 FH UNDIP Semarang

Tim LBH Pers. 2009. Proses Penanganan Perkara Pers. Jakarta: Yayasan LBH Pers.USAID.drsp 